\title{
Prolonged oestrus as a cause of infertility in dairy cattle - A review
}

\author{
Arsha Shaji, Kamaraj Elango and Arumugam Kumaresan
}

Received: 13 August 2021 / Accepted: 18 August 2021 / Published online: 31 October 2021

(C) Indian Dairy Association (India) 2021

\begin{abstract}
Prolonged oestrus is one of the conditions associated with perturbed follicular dynamics that culminates into substantial economic losses to dairy industries through low success rate of artificial insemination, increased inter-calving period, reducing total milk yield, lowering calf production, shortening reproductive life of the animals, lowering fertilisation rate and abnormal embryonic development. Prolonged oestrus is characterized by the exhibition of extended duration of oestrus in various breeds of cattle. Cows having prolonged oestrus need to be examined at frequent intervals for determining the correct time of artificial insemination. This makes it challenging to inseminate the animals at the correct time, which is a major inconvenience for the field veterinarians and farmers. Since the follicular dynamics in cows is intricate to comprehend, the disorders in which also often go unnoticed and not treated/managed wisely in the field conditions. Therefore, it is of paramount importance to understand the aetiology of prolonged oestrus so that strategies to improve fertility could be designed. Alterations in hypothalamohypophyseal-gonadal axis, which is also influenced by some other extrinsic factors like stress, nutrition, age, parity, breed etc., apart from the endocrine alterations could cause the prolonged dominance of follicle. The presence of suprabasal
\end{abstract}

Theriogenology Laboratory, Veterinary Gynaecology and Obstetrics, Southern Regional Station of ICAR- National Dairy Research Institute, Bengaluru, Karnataka 560030, India

Arumugam Kumaresan $(\bowtie)$

Theriogenology Laboratory, Veterinary Gynaecology and Obstetrics, Southern Regional Station of ICAR- National Dairy Research Institute, Bengaluru, Karnataka 560030, India.

Mobile: +91 - 9671673108; Email: ogkumaresan@gmail.com progesterone and luteal insufficiency are considered as the main cause of this condition among cattle. In this review, we attempted to analyse the prior art on the topic and to delineate the possible causes, and to suggest managemental strategies to mitigate the prolonged oestrus condition in dairy cows

Keywords: Cattle, Follicular dynamics, Fertility, Suprabasal progesterone, Prolonged oestrus, Repeat breeding

\section{Introduction}

The profitability of dairying depends to a large extent on the efficiency of reproduction. Maximizing reproductive efficiency requires the matching of genotypes to the production environment in order to ensure that the calving intervals are short and the rates of conception to artificial breeding are high. However, when the reproductive efficiency of the dairy cows are analysed, based on the records, it was observed that the conception rates are low (country's average is $35 \%$ ) and the calving intervals are quite high. One of the important reasons for extended calving interval is repeat breeding. It has been reported that the incidence of repeat breeding in cattle ranged from 5.5 to $33 \%$. It is also reported that one of the most significant reason for repeat breeding in high producing crossbred cows is prolonged oestrus and associated alterations in the endocrine profile.

Prolonged oestrus is a condition in which the duration of oestrus and the interval between the onset of oestrus and ovulation interval both are exceeding the normal range. In some cases, the duration of oestrus has been reported to be greater than $36 \mathrm{hrs}$, which can vary from 2-7 days (Bage et al. 2002; Bloch et al. 2006). At field conditions, the inseminators/veterinarians are baffled to precisely time the insemination. Prolonged oestrus condition can increase the number of services per conception to more than 4 against the optimum of $<2$. In addition, it also increases the intercalving period and decreases the total milk yield, fertilisation rate, embryo development and calf production (Government of Kerala-Economic Review, 2015). Prolonged oestrus has been reported to be observed in $50 \%$ of repeat breeder cows (Cummins et al. 2012; Ghuman et al. 2014; Arun et al. 2020). The conception rate in cows showing prolonged oestrus decreased drastically as the duration of oestrus increased (Nebel et al. 2000). The 
conception rate for the animals exhibiting prolonged oestrus was reported as $70 \%, 80 \%, 41.66 \%$ in two, three- and four-days duration, respectively (Nath 2014). Although several treatment protocols have been evaluated for their effectiveness in treating the condition, their effect is variable and inconsistent (Nakao et al. 1984; Shelar et al. 2002; Shakir 2018). To develop a suitable management and therapeutic strategy for management of prolonged oestrus condition and to achieve high conception rates in cows affected with the condition, it is essential to understand the underlying aetiology. However, systematically organized and analysed reviews are not available on the topic; therefore, in this review we attempted to analyse the prior art on the topic and to delineate the possible causes, and to suggest managemental strategies to mitigate the prolonged oestrus condition in dairy cows.

\section{Incidence and duration of prolonged oestrus}

The incidence of prolonged oestrus in cattle of different regions are shown table 1 . has been reported as 26.6 and $21.62 \%$ among crossbred cattle in Kerala maintained under field and farm conditions, respectively (Jeba-Sujana, 2005). Nearly, 30-40\% of repeat breeder crossbred cows displayed prolonged oestrus ie, about 37-60 hrs against the normal duration of 24-36 hrs. Moreover, $70 \%$ of these repeat breeder animals had suprabasal plasma progesterone $(>1 \mathrm{ng} / \mathrm{ml})$ at oestrus (Bage et al. 2002; Singh 2003, Dadarwal et al. 2005 and Singh et al. 2009). The low progesterone $(1 \mathrm{ng} / \mathrm{ml})$ is vital for conception and favours typical fern pattern in cervical mucus, but when progesterone increases, the typical pattern changes to atypical fern pattern or nil pattern (Kumaresan et al. 2001). Parvathy (2015) reported that $21.78 \%$ of prolonged oestrus conditions among the crossbred cows reared under farm conditions. Bedi et al. (2007) observed that out of 1332 oestrus in crossbred cows, $21.9 \%$ of crossbred cows exhibited oestrus period for less than $24 \mathrm{hrs}$, whereas $48.9 \%$ of cows exhibited oestrus period for 24-36 hrs and $30.05 \%$ of cows exhibited oestrus period for more than $36 \mathrm{hrs}$. Study conducted on crossbred cattle by Das (2017) recorded that the incidence of prolonged oestrus was about $14.24 \%$, and $7.60,8.04$ and $1.06 \%$ of cows showed oestrus for 2-, 3- and 4-days duration, respectively. The duration of prolonged oestrus in cattle of different regions are shown table 2. The variation in the incidence of prolonged oestrus in crossbred cows may be due to differences in the breeds of cattle and their environment, level of nutrition and stress factor affecting the animals.

\section{Suprabasal progesterone concentration and prolonged oestrus}

Elevated progesterone concentrations during oestrus extended the secondary signs of oestrus due to persistence of preovulatory follicle (Duchens et al. 1995a). The marginal rise in serum progesterone level during oestrus affected the expression of normal oestrus signs, hormonal synchrony around oestrus and disturbances in ovulation leading to poor fertility in dairy cows. In addition, delay in ovulation due to increased plasma progesterone in oestrus leads to ageing of oocyte and reduced conception rate (Duchens et al. 1995a, Meier and Bruke 2010). An abnormal serum progesterone concentration was observed in repeat breeder cows with prolonged oestrus $(0.5-1.0 \mathrm{nmol} / \mathrm{L})$ against the normal basal value of $<0.5 \mathrm{nmol} / \mathrm{L}$ during oestrus (Albihn et al. 1991; Båge et al. 1997; Gustafsson et al. 1986; Singh et al. 2009). Layek et al. (2013) stated an extended interval from oestrus to ovulation in cows, which had progesterone level greater than $1 \mathrm{ng} / \mathrm{ml}$, compared to the cows that had normal progesterone concentration (less than $1 \mathrm{ng} / \mathrm{ml}$ ) during oestrus. Parvathy (2015) observed that the animals exhibited prolonged oestrus had increased progesterone level during oestrus and luteal insufficiency during mid luteal stage.

Table 1 Incidence of prolonged oestrus in cattle of different region

\begin{tabular}{llll}
\hline Incidence & Breed & Place & Reference \\
\hline $\begin{array}{l}30-40 \% \text { repeat breeder cows } \\
46.1 \% \text { delayed ovulation }\end{array}$ & Swedish Red \& White Breed Sweden & Bage et al. 2002 \\
26.6 and $21.62 \%$ & Crossbred cows & Germany & Braun and Sarmento 2004 \\
$30-40 \%$ repeat breeder cows & HF x Sahiwal & India (Kerala) & Jeba-Sujana 2005 \\
& & India (Punjab) & Dadarwal et al. 2005 \\
& & & Bedi et al. 2007 \\
$29.33 \%$ delayed ovulation in repeat breeder & Crossbred cows & India (Assam) & Das 2017 \\
$20-30 \%$ & Crossbred cows & India & Nanda and Singh, 2008 \\
$51.47 \%$ repeat breeder & Crossbred cows & India (Kerala) & Parvathy 2015 \\
$31.82 \%$ & Crossbred cows & Croatia & Zobel et al. 2009 \\
$19.86 \%$ & HF & & \\
$5.88 \%$ & Simmental & India & Ghuman et al. 2014 \\
$50 \%$ repeat breeder & Crossbred cows & India (Kerala) & Mathew et al. 2014 \\
$59.64 \%$ & Crossbred cows & India (Kerala) & Shakir 2018 \\
$25.86 \%$ & Crossbred cows & India (Guwahati) & Das 2017 \\
$14.24 \%$ & Crossbred cows & India (Assam) & Nath et al. 2019 \\
$16.75 \%$ & Crossbred cows & India (Kerala) & Arun et al. 2020 \\
$25.96 \%$ & Crossbred cows & & \\
\hline
\end{tabular}


One of the foremost reasons for prolonged oestrus exhibition by the cattle is the abnormal prolongation of the life of dominant follicle, which ultimately leads to delayed ovulation. Normally the oestrus to ovulation interval in cows is about 25-35 hours; the onset of oestrus to LH surge occurs at about $9 \mathrm{hr}$ i.e., about 18-26 hrs before ovulation (Saumande and Humblot, 2005). As far as when the chronology of different events is concerned, peak concentrations of estradiol-17â is observed at $6.8 \mathrm{hr}$, the LH surge occurs at $9.1 \mathrm{hr}$ and the ovulation occurs at $29.4 \mathrm{hr}$ after the onset of oestrus (Stevenson et al. 1998, Saumande and Humbolt, 2005). A follicle that persists beyond its normal time is called as prolonged dominant follicle and is the main reason for the prolonged oestrus condition. Delayed ovulation of the follicle can be assessed using three parameters, which include (i) the interval from oestrus to LH surge (ii) the interval from LH surge to ovulation and (iii) the interval from oestrus to ovulation (Saumande and Humbolt, 2005; Bloch et al. 2006; Meier \& Bruke 2010).

In several studies, it has been stated that the interval between the onset of oestrus and ovulation was more variable than the interval between the LH peak and ovulation (Rajamahendran et al. 1989; Saumande and Humbolt, 2005; Niyas et al. 2019). The endocrine milieu in which the preovulatory follicle grows determines its persistency. The problem may lie at the level of hypothalamus to release normal $\mathrm{GnRH}$, which in turn can delay the pituitary LH surge leading to delayed LH surge or untimely LH surge (Pursley et al. 1995; Saumande and Humbolt, 2005). In addition, the increase in the time period between the LH surge and the time of ovulation can be due to problems at the ovarian cellular level and its microenvironment, which may occur due to effect of suprabasal progesterone (Duchens et al. 1995a, Duchens et al. 1996).

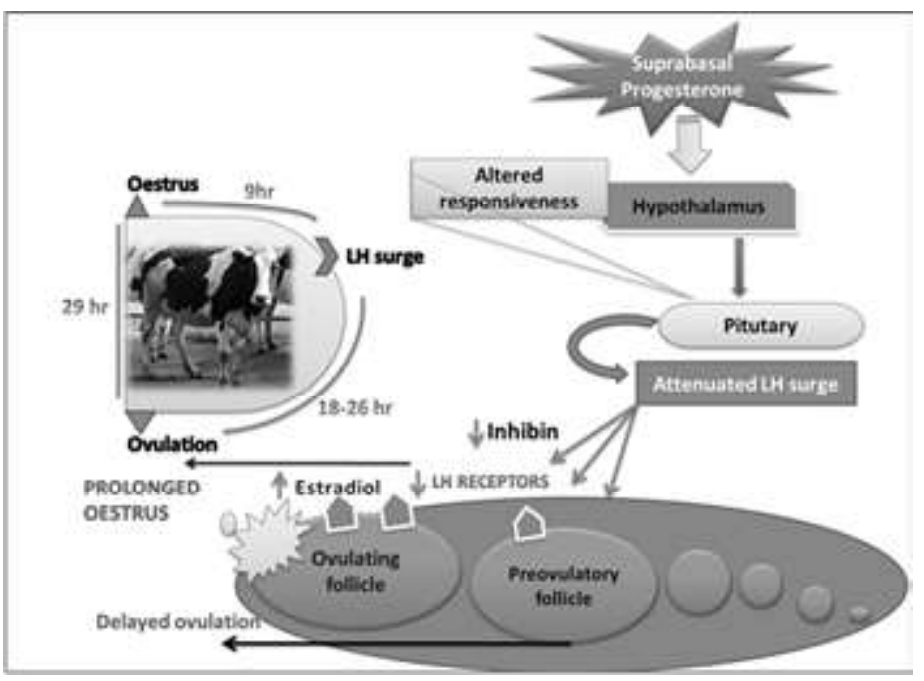

Fig. 1 Hypothetical model on the effect of suprabasal progesterone concentrations on hypothalamo-hypophysealovarian axis and oestrus duration

The most accepted cause for prolonged oestrus in cattle is the presence of suprabasal progesterone of about $>0.5 \mathrm{ng} / \mathrm{ml}$ or the delayed ovulation (Singh et al. 2009). The elevated level of progesterone in turn results in altered LH pulse frequency (Bridges and Fortune, 2003). It is reported that suprabasal progesterone is due to the result of incomplete luteolysis and some extra-gonadal source like adrenal which can elevate the basal progesterone level when the cows are exposed to stress (Honparke et al. 2010). The effect of suprabasal progesterone on the hypothalamo-hypophyseal-ovarian axis, which alters interval between i) oestrus to LH surge, ii) LH surge to ovulation and iii) oestrus to ovulation to prolong the duration of oestrus by

Table 2 Duration of prolonged oestrus in cattle

\begin{tabular}{lllc}
\hline Duration of prolonged oestrus & Breed & Place & Reference \\
\hline $65.3 \pm 15.3 \mathrm{hr}$ & Swedish Red \& White breed & Sweden & Bage et al. 2002 \\
$42.66 \pm 2.74 \mathrm{hr}$ & Crossbred cattle & India (Punjab) & Singh, 2003 \\
$90.48 \pm 20 \mathrm{hr}$ in repeat & HF×Sahiwal & India (Punjab) & Dadarwal et al. 2005 \\
breeder cows & & & \\
$58.0 \pm 5.29 \mathrm{hr}$ & Swedish Red and White breed & Sweden & Singh et al. 2005 \\
$65.65 \pm 2.57 \mathrm{hr}$ & Crossbred cows & India (Kerala) & Jeba-Sujana, 2005 \\
$>36 \mathrm{hr}$ & Crossbred cows & India (Punjab) & Bedi et al. 2007 \\
$33.27 \pm 1.56 \mathrm{hr}$ in delayed & Crossbred cows & India (Guwahati) & Das et al. 2009 \\
ovulation & & & \\
$72.00 \pm 4.17 \mathrm{hr}$ in delayed & Crossbred Jersey cows & India (Kashmir) & Bhat and Bhattacharyya \\
$\begin{array}{l}\text { ovulation } \\
36-80 \mathrm{hr}\end{array}$ & Crossbred cows & India (Punjab) & 2012 \\
$\begin{array}{l}\text { Repeat breeder cows } \\
37-80 \mathrm{hr} \text { repeat breeder cows }\end{array}$ & Crossbred cattle & India (Punjab) & Singh et al. 2012 \\
$>96 \mathrm{hr}$ & HF crossbred cattle & India (Kerala) & Ghuman et al. 2014 \\
$73.36 \pm 3.14 \mathrm{hr}$ repeat & Crossbred cattle & India (Tamilnadu) & Mathew et al. 2016 \\
breeder cows & & & Senthilkumar et al. \\
$84.0 \pm 6.26 \mathrm{hr}$ & Crossbred cows & India (Tirupathi) & 2017 \\
& & & Radhika 2017 \\
\hline
\end{tabular}


affecting the ovarian microenvironment is shown in figure 1. Nanda and Singh, (2008) stated that the factors like lactational and nutritional stress were the major reasons for the occurrence of suprabasal progesterone and prolonged oestrus among dairy cattle. This elevated suprabasal progesterone inhibits IGF-1 secretion and reduces responsiveness of follicular cells to $\mathrm{LH}$ (Omari et al. 2020). The maintenance of prolonged dominant follicle may cause premature maturation of the oocyte which causes the chromosomes to condense and the meiosis to progress to metaphase II before LH surge. It is also stated that embryos obtained from cows that ovulated from persistent follicles were compromised and could not reach the 16- cell stage (Ahmad et al. 1995).

In a study, it was reported that relative risk of a cow becoming repeat breeder was $58 \%$ and $42 \%$, when the $\mathrm{AI}$ is performed at suprabasal progesterone level and basal progesterone level, respectively (Bage 2003). Delayed LH surge and extended LH pulse frequency delays ovulation and ultimately results in preovulatory ageing of the oocyte (Singh et al. 2005). The estrogen: progesterone ratio should be greater than 1 for a normal ovulation to occur. The presence of suprabasal progesterone reduces the tubal contractility and impairs transport of sperm from sperm reservoir (Bloch et al. 2006). Recently, a study conducted on the differential abundance of proteins in follicular fluids from preovulatory follicles of less fertile dairy cows, reported the increased abundance of TIMP2, which can disrupt the tissue remodelling necessary for ovulation which leads to delayed ovulation and suggested to have a prolonged heat onset to ovulation interval in low fertile cows (Zachut et al. 2016).

\section{Predisposing factors for prolonged oestrus in cattle}

\section{Stress factors}

Stress can be of several types which includes environmental, managemental, physical or social stress. These kind of stresses were stated to be the causative agent for sustained stimulation of adrenal glands, which could be a factor for occurrence of suprabasal progesterone during prolonged oestrus (Bage et al. 2000). Generally, heat stress is associated with a lot of physiological changes that cause immediate and delayed negative effects on secretion of gonadotropins, follicular dynamics, ovulation, corpus luteum development, steroidogenesis, oocyte developmental competence, embryonic survival, utero-placental function, lactation and post-natal development. Heat stress particularly reduces follicular dominance by inducing multiple large follicles as well as prolonged dominant follicles (Hansen 2009). Alteration in high tonic FSH availability disturbs normal follicular selection and dominance. Altered LH surge and negative energy balance during heat stress can disrupt the normal oocyte maturation (eg; premature meiosis) and reduces developmental competence (Mihm et al. 1994). Heat stress will depress follicular oestradiol due to reduced theca cell androstenedione production associated with low 17-alpha-hydroxylase expression and reduced aromatase activity in granulosa cells. Thereby, heat stress reduces follicular dominance by inducing multiple large follicles as well as prolonged dominant follicles (Wolfenson et al. 2000, Hansen 2009).

Heat stress causes some direct effects on oocytes like, oxidative damage, apoptotic cell death, irreversible changes on cytoskeleton and meiotic spindle, which will interfere with cell division, reduced mRNA and protein reserves for early embryonic development and altered membrane integrity which effects both the signal transduction and protein transport (Hansen 2009). In addition, heat stress causes major differences in gene transcript levels of DNA binding proteins, transcription factors, Erg-1, progesterone, and prostaglandin receptors ultimately leads to reduced oocyte competence which results in poor fertility rate after insemination (Wakayo et al. 2015). During hot season, in order to maintain body temperature, imbalances in energy metabolism occurs. This would lead to suppressed activity of aromatase enzyme in granulosa cells and retard the functionality of dominant follicles (Wolfenson et al. 2000). Roth et al. (2000) stated that follicular microenvironment was adversely affected by elevated exposure of temperature and will lead to deterioration of functioning dominant follicles. Thus, the ovulatory follicle might require more time and a larger size for attaining ovulation under heat stress and such follicles would be of inferior quality and lead to yield poor quality oocytes and subsequent infertility (Hansen 2009). Satheshkumar et al. (2015) studied natural influence of season on Indian crossbred cows and found that the ovulatory wave emerged significantly earlier (Day 11.5) and the dominant follicle of that wave had a prolonged growth phase (11days) during summer compared to the cold season (days 14.8 and 5.8 respectively). They concluded that increased incidence of two follicular wave cycles which accounted for the persistence and aging of the follicle at the time of ovulation and altered luteal endocrine activity might be the reasons for the diminished fertility in crossbred cattle during hot season. Lactational and nutritional stresses are also considered to be the major reasons for the occurrence of suprabasal progesterone and prolonged oestrus among dairy cattle (Nanda and Singh, 2008).

\section{Age and Parity}

Occurrence of prolonged oestrus among repeat breeder cows were also influenced by age and parity of the cows, mainly because of underlying endocrine disturbances, nutritional and production stress as the age and parity increases. In several studies, it was reported that, cows of parity four and above in an age group of 8-12 years were more prone to be repeat breeder exhibiting prolonged oestrus. These may occur due to negative energy balance which alters the insulin responsiveness of the follicle, altered prostaglandin synthesis, CL function, anatomical defects due to increased parity and age (Singh et al. 2012, Asaduzzaman et al. 2016, Arun et al. 2020). 


\section{Nutritional causes}

Negative energy balance is also a cause for alteration of function, development, and maintenance of follicles. It is strongly correlated with low concentrations of glucose, insulin, IGF-1, and secretion of gonadotropins, which ultimately leads to low FSH and LH peaks and hence results in anovulation. IGF-1 has a key role in follicular development, reduction in its concentration during negative energy balance reduces ovarian responsiveness to $\mathrm{LH}$ stimulation. Decreased insulin can cause anovulation by interfering normal LH pulses and FSH pulses. Low IGF-1 and insulin together reduces the responsiveness of follicles towards LH and thereby suppress follicular oestradiol production (Omari et al. 2020).

The dairy cattle reared in small holder production system are deficit in most of minerals (Kumaresan et al. 2010), which can impact reproductive performance (Kumaresan et al. 2009). In addition, the minerals and their deficiency were area specific, especially the correlation between calcium level in soil and in cattle were reported (Kumaresan et al. 2010). Calcium-Calmodulin system participates in the regulation of steroidogenesis at different stages of granulosa cell differentiation, thereby affecting the growth of preovulatory follicles (Kendell et al. 2003). It has effects on gonadotropin regulation, independent of stage of follicular maturation and cellular differentiation. Calcium also has a role in influencing delivery of cholesterol by mitochondria or by stimulating conversion of pregnenolone to progesterone in the adrenal gland and ovaries (Wiederkehr et al. 2011). Calcium dependent mechanism has a role in the luteinising hormone release from the pituitary gland. Calcium also plays a key role in increasing the number and size of ovarian preovulatory follicles as well as ovulation rate (El-Shahat and Maaty 2010). Marginal deficiency of phosphorus could cause disturbances in the pituitary-ovarian axis including ovulation. Inorganic phosphorus is essential for normal phospholipid metabolism, cAMP synthesis, energy transformation at cellular level, and integral part of many coenzymes may be a key to its effect on reproduction.

The effect of dietary supplementation with calcium salts of long chain fatty acids with or without of L-carnithine on ovarian activity was studied by El-Shahat and Maaty (2010). They found that calcium played a key part in improving the number and size of ovarian preovulatory follicles as well as ovulation rate. Significantly $(p<0.01)$ lower level of inorganic phosphorus $(3.73 \pm 0.29 \mathrm{mg} / \mathrm{dL})$ in infertile repeat breeder cows than normal cyclic cows $(5.06 \pm 1.19 \mathrm{mg} / \mathrm{dL})$ was reported by Awasthi and Kharche, (1987). Das et al. (2009) observed that the serum inorganic phosphorus concentration was significantly higher in the animals with normal ovulation $(5.45 \pm 0.15 \mathrm{mg} / \mathrm{dl})$ than the animals with anovulation $(4.45 \pm 0.14 \mathrm{mg} / \mathrm{dl})$. However, Nath et al. $(2014 ; 2019)$ recorded the mean serum calcium and phosphorus levels in prolonged oestrus cows did not differ among different days of prolonged oestrus.
Deficiency of zinc can cause reduction in GnRH secretion by hypothalamus and decreases the levels of FSH and LH and results in anovulation (Karaca et al. 2007). It is a co-factor for more than 300 metalloenzymes in DNA synthesis and gene transcription. Zinc in proteins can either participate directly in chemical catalysis or maintain protein structure and stability. Zinc finger proteins implicated in gene expression of receptors of the steroid hormones which are involved in reproduction. Das et al. (2009) reported the concentration of $\mathrm{Zn}(\mathrm{ppm})$ was significantly $(\mathrm{p}<0.01)$ lower in the animals with anovulation $(0.85 \pm 0.03)$ and delayed ovulation $(1.41 \pm 0.04)$ compared to the animals with normal ovulation $(1.78 \pm 0.02)$. Ahmed et al., 2017 reported that the plasma concentration of zinc $(\mu \mathrm{g} / \mathrm{dl})$ was significantly higher $(\mathrm{p}<0.05)$ in normal cyclic cows $(26.4 \pm 17.4)$ than in repeat breeder $(18.8 \pm 17.7)$ crossbred cows.

\section{Strategies for improving fertility in cows exhibiting prolonged oestrus}

The regulation of follicular dynamics by inducing the occurrence of three follicular wave cycles might be a potential target for therapeutic intervention of summer infertility syndrome in crossbred cows (Satheshkumar et al. 2012). The conception rate in prolonged oestrus crossbred cows was found to be $70 \%, 80 \%, 41.66 \%$ in two, three- and four-days duration of oestrus, respectively (Nath et al. 2014). The prolonged oestrus exhibited by the repeat breeder cows amplified the risk of poorly timed AI, which resulted in reduced conception rate (Nebel et al. 2000). A higher pregnancy rate was achieved when the period of dominance was restricted to 1-4 days, whereas dominance of $>10$ days was associated with no pregnancies and concluded that pregnancy rate decreases with the increase in duration of dominance (Viñoles et al. 2001). The duration of dominance for optimum fertility is less than 8 days. Reducing the period of follicle dominance by optimizing the ovulatory response to the initial GnRH injection of synchronization protocol improved early embryo development (Cerri et al. 2009). Reduction in embryo quality was observed even when concurrent extension of follicle dominance was of only $1.5-2$ days (Cerri et al. 2009). Period of dominance is more important for early embryo quality in high producing lactating dairy cows than the endocrine steroidal milieu in which the ovulatory follicle develops. High producing cows with extended interval between follicle deviation to oestrus have reduced fertility because embryo quality is compromised when dominance of the ovulatory follicle is increased by as few as 1.5 days (Cerri et al. 2009). Pregnancy rate of the cows that ovulates $24 \mathrm{hr}$ after the oestrus onset can be optimized through repeated insemination every $24 \mathrm{hr}$ till the occurrence of ovulation (Van-Eerdenburg et al. 2002). However, the oocytes from delayed ovulating follicles are abnormal due to the extended growth period and therefore repeated AIs may be unsuccessful (Duchens et al. 1995b). 
In crossbred cows the mean duration of oestrus before treatment with $1500 \mathrm{IU}$ hCG was $70.50 \pm 4.20 \mathrm{hrs}$ and after the treatment it was $47.25+2.39$. The mean duration of oestrus was $48.62+1.84 \mathrm{hr}$ when treated with $3000 \mathrm{IU}$ hCG as against $69 \pm 4.39 \mathrm{hrs}$ in the control (Mathew et al. 2016). Senthilkumar et al. (2017) studied 60 repeat breeder cows with the history of prolonged oestrus and noticed that the mean duration of oestrus before hormonal therapy was $75 \pm 3.71 \mathrm{hr}$. However, the duration was reduced to $48.21 \pm 3.12$ $\mathrm{hr}$ after the treatment with $1500 \mathrm{IU}$ hCG or $10 \mu \mathrm{g} \mathrm{GnRH}$ analogue at the time of insemination. The slow ovulatory follicle growth and corpus luteum regression could be associated with the persistence of oestrus characters which can be optimised following PGF2á administration during early luteal phase of cows followed by timely insemination and improved conception rate (Ghuman et al. 2014; Shakir 2018).

$\mathrm{GnRH}$ or its analogues are indicated for inducing ovulation close to the time of insemination to enhance conception rates as they stimulate acute release of $\mathrm{LH}$ and $\mathrm{FSH}$ from anterior pituitary (Shaw 1999). Fertility improved in some studies when GnRH was administered between days 11 and 14 in lactating dairy cows (Drew and Peters, 1994) but not in other studies (Jubb et al. 1990; Stevenson et al. 1993, Bartolome et al. 2005). GnRH can be used in the prolonged oestrus cows as they are affected with delayed ovulation and/or suboptimal functioning of corpus luteum (Bedi et al. 2007). The conception rate in repeat breeder crossbred cattle having prolonged oestrus was $50 \%$ and $42.80 \%$ following intramuscular injection of $2.5 \mathrm{~mL}$ of Buserelin acetate after single and double insemination, respectively (Sharma et al. 2006). The double injection of Buserelin $(\mathrm{GnRH})$ is efficient in improving the conception rates in prolonged oestrus repeat breeding crossbred cattle. The conception rate in the cows those were administered Buserelin $(20 \mu \mathrm{g}) 6 \mathrm{hrs}$ before AI and again on day 12 were significantly higher $(52 \%)$ than those were given single Buserelin $(20 \mu \mathrm{g}) 6$ hrs before AI (34\%) (Dadarwali et al. 2007).

\section{Conclusions}

Prolonged oestrus in dairy cattle baffles field veterinarians in deciding the appropriate time of insemination ultimately leading to reduced conception rates and repeat breeding. As a managemental measure the animal should be maintained under normal energy balance and minerals like calcium, phosphorus and zinc level should be maintained at adequate levels in the feed of cows. In cows showing prolonged oestrus, reducing the period of follicle dominance by administration of $\mathrm{GnRH} / \mathrm{LH}$ will be advantageous. Pregnancy rate of the cows that ovulates $24 \mathrm{hr}$ after the oestrus onset can be improved through repeated insemination every $24 \mathrm{hr}$ till the occurrence of ovulation. Use of different regimens of $\mathrm{GnRH}$ shots were reported to have more significant improvement in the prolonged oestrus condition, by its action to induce ovulation and prevent luteal insufficiency. The $1500 \mathrm{IU}$ hCG or $10 \mu \mathrm{g} \mathrm{GnRH}$ analogue at the time of insemination can be tried to reduce the duration of oestrus in the cows having prolonged oestrus. However, further studies needed to determine the oocyte quality, probably in terms of genomics, in prolonged follicle and other risk factors associated with prolonged follicular dominance.

\section{References}

Ahmad N, Neal SF, Butcher RL, Keith IE (1995) Effect of persistent follicles on early embryonic losses in beef cows. Biol Reprod 52: 1129-1135

Ahmed ME, Ahmed FO, Frah EA, Elfaki I (2017) Blood biochemical profile of Sudanese crossbred repeat breeder cows. Afr J Biotechnol 16: 366-370

Albihn A, Shamsuddin M, Qunshan H, Kindahl H (1991) Plasma Levels of Prostaglandin F 2á Metabolite and Progesterone in Repeat Breeder Heifers. Acta Vet Scand 32: 361-371

Arun HD, Becha BB, Jayakumar C, Unnikrishnan MP, Ajith, KS, Kurien, MO (2020) Occurrence of repeat breeding and prolonged oestrus in crossbred cattle. J Vet Anim Sci 51: 132-135

Asaduzzaman KM, Bhuiyan MMU, Rahman MM, Bhattacharjee J (2016) Prevalence of repeat breeding and its effective treatment in cows at selected areas of Bangladesh. Bangladesh J Vet Med 14: 183-190

Awasthi MK., Kharche KG (1987) Studies on some constituents in normal cycling, fertile and infertile repeat breeder crossbred cows. Indian J Anim Reprod 8: 95-97

Båge R (2003) Conception rates after AI in Swedish red and white dairy heifers: relationship with progesterone concentrations at AI. Reprod Domest Anim 38: 199-203

Båge R, Forsberg M, Gustafsson H, Larsson B, Rodrýguez-Martýnez H (2000) Effect of ACTH-challenge on progesterone and cortisol levels in ovariectomised repeat breeder heifers. Anim Reprod Sci 63: $65-76$

Båge R, Gustafsson H, Forsberg M, Larsson B, Rodriguez-Martinez H (1997) Suprabasal progesterone levels in repeat breeder heifers during the pro-and oestrous period. Theriogenology 1: 141

Båge R, Gustafsson H, Larsson B, Forsberg M, Rodrýguez-Martýnez H (2002) Repeat breeding in dairy heifers: follicular dynamics and estrous cycle characteristics in relation to sexual hormone patterns. Theriogenology 57: 2257-2269

Bartolome, JA, Melendez P, Kelbert D, Swift K., McHale J, Hernandez J, Archbald LF (2005) Strategic use of gonadotrophin-releasing hormone $(\mathrm{GnRH})$ to increase pregnancy rate and reduce pregnancy loss in lactating dairy cows subjected to synchronization of ovulation and timed insemination. Theriogenology 63: 1026-1037

Bedi M, Singh J, Gandotra VK, Dadarwal D, Dhaliwal GS (2007) Incidence of repeat breeding, variation of fertile estrus with respect to season and duration of estrus and progesterone profile of repeat breeding crossbred cattle. Indian J Anim Sci 77: 355-358

Bhat FA, Bhattacharyya HK (2012) Oestrus duration and status of reproductive organs in repeat breeding cows. Iran J Appl Anim Sci 2: 295-299

Bloch A, Folman Y, Kaim M, Roth Z, Braw-Tal R, Wolfenson, D (2006) Endocrine alterations associated with extended time interval between estrus and ovulation in high-yield dairy cows. J Dairy Sci 89: 46944702

Braun J, \& Sarmento S. (2004). Delayed ovulation in dairy cattle a field study. Tierarztl Umsch 59: 64-68

Bridges PJ, Fortune JE (2003) Characteristics of developing prolonged dominant follicles in cattle. Domest Anim Endocrinol 25: 199-214 
Cerri RL, Rutigliano HM, Chebel RC, Santos JE (2009) Period of dominance of the ovulatory follicle influences embryo quality in lactating dairy cows. Reproduction 137: 813-823

Cummins SB, Lonergan P, Evans ACO, Butler, ST (2012) Genetic merit for fertility traits in Holstein cows: II. Ovarian follicular and corpus luteum dynamics, reproductive hormones, and estrusn behavior. J Dairy Sci 95: 3698-3710

Dadarwal D, Singh J, Honparkhe M, Cheede GS, Kang RS (2005) lnvestigations on repeat breeding crossbred cattle with history of prolonged estrus. Indian J Anim Sci 75: 922-924

Dadarwali D, Honparkhe M, Singh GCI, Kumar A (2007) Efficacy of double injection buserelin improving pregnancy rates oestrus repeat breeding crossbred cattle. Indian J Anim Sci 77: 544-548

Das JM, Dutta P, Deka KC, Biswas RK, Sarmah, BC, Dhali A (2009) Comparative study on serum macro and micro mineral profiles during oestrus in repeat breeding crossbred cattle with impaired and normal ovulation. Livest Res Rural Dev 21: http://www.lrrd.org/lrrd21/5/ das $21072 . h t m l$.

Das N (2017) Study on prolonged oestrus in crossbred cattle. MVSc. Thesis.Assam Agricultural University, Khanapara Guwahati, Assam

Drew SB, Peters AR (1994) Effect of buserelin on pregnancy rates in dairy cows. Vet Rec Open 134: 267-269

Duchens M, Forsberg M, Gustafsson H, Edqvist LE, Rodriguez-Martinez H (1995a) Reproductive performance of heifers induced to estrus asynchrony by suprabasal plasma progesterone levels. Anim Reprod Sci 39:171-182

Duchens M, Maciel M, Gustafsson H, Forsberg M, Rodriguez-Martinez H, Edqvist LE (1995b) Influence of perioestrous suprabasal progesterone levels on cycle length oestrous behaviour and ovulation in heifers. Anim Reprod Sci 37: 95-108

Duchens M, Rodriguez-Martinez H, Forsberg M, Gustafsson H (1996) Ultrastructure of bovine ovarian follicles induced to extended growth by perioestrous suprabasal progesterone levels. Acta Vet Scand 37: 239-250

El-Shahat KH, Maaty AMA (2010) The Effect of Dietary Supplementation with Calcium Salts of Long Chain Fatty Acids and/ or I-carnitine on Ovarian Activity in Rahmani Ewes. Anim Reprod Sci 117: 78-82

Ghuman SPS, Honparkhe M, Dadarwal D, Dhaliwal G (2014) Optimizing estrous period characteristics of crossbred cows exhibiting prolonged estrus using a PGF2á analogue. Indian J Anim Sci 84: 15-17

Government of Kerala (2015). Economic Review, State Planning Board, Thiruvananthapuram 53-60

Gustafsson H, Larsson K, Kindahl H, Madej A (1986) Sequential endocrine changes and behaviour during oestrus and metoestrus in repeat breeder and virgin heifers. Anim Reprod Sci 10: 261-273

Hansen PJ (2009) Effects of heat stress on mammalian reproduction. Philosophical Transactions of the Royal Society B: Biol Sci 364: 3341-3350.

Honparkhe M, Singh J, Dadarwal D, Ghuman SPS, Dhaliwal GS and Kumar $\mathrm{A}(2010)$ Effect of midluteal phase GnRH treatment in repeat breeder cattle. Indian Vet J 87: 351-354.

Jeba-Sujana D (2005) Fertility trials on induced oestrum in repeat breeding cattle with prolonged oestrum, M.V.Sc Thesis, College of Veterinary and Animal Sciences, Mannuthy

Jubb TF, Abhayaratne D, Malmos J, Anderson GA (1990) Failure of an intramuscular injection of an analogue of gonadotrophin releasing hormone 11 to 13 days after insemination to increase pregnancy rates in dairy cattle. Aust Vet J 67: 359-361

Karaca Z, Tanriverdi F, Kurtoglu S, Tokalioglu S, Unluhizarci, Kelestimur $\mathrm{F}$ (2007) Pubertal arrest due to $\mathrm{Zn}$ deficiency. The effect of zinc supplementation. Hormones (Athens) 6: 71

Kendall NR, Marsters P, Scaramuzzi RJ and Campbell BK (2003) The effect of copper chloride and ammonium tetrathiomolybdate on bovine ovarian follicle granulosa cells cultured in serum free media. Reproduction 125: 657-665

Kumaresan A, Ansari MR, Rawal CVS, Purbey LN, Sanwal PC (2001) Influence of plasma progesterone level and cervical mucus fern pattern on conception rate in bovines. Indian J Anim Reprod 1: 8384

Kumaresan A, Bujarbaruah KM, Pathak KA, Ramesh T (2010) Soil-plantanimal continuum in relation to macro and micro mineral status of dairy cattle in subtropical hill agro ecosystem. Trop Anim Health Prod 42: 569-577

Kumaresan A, Prabhakaran PP, Bujarbaruah KM, Pathak KA, Chhetri B, Ahmed SK (2009) Reproductive performance of crossbred dairy cows reared under traditional low input production system in the eastern Himalayas. Trop Anim Health Prod 41: 71-78

Layek SS, Mohanty TK, Kumaresan A, Behera K, Chand S (2013) Cervical mucus characteristics and periestrual hormone concentration in relation to ovulation time in Zebu (Sahiwal) cattle. Livest Sci 152: 273-281

Mathew RM, Ghosh KNA, Harshan HM, Kurien MO (2014) Prolonged oestrum and its occurrence among repeatbreeding cattle of Kerala. Indian Vet J 91: 46-47

Mathew RM, Ghosh KNA, Metilda J, Bibin B (2016) hCG for enchancing the conception rate in prolonged estrum repeat breeding cattle. Indian Vet J 93: 22-24

Meier S, Burke CR (2010) Understanding mechanisms contributing to reduced fertility: The reproductive physiology of sub-fertility. In Proceedings of the 4th Australasian Dairy Science Symposium. pp. 417

Mihm M, Baguisi A, Boland MP, Roche JF (1994) Association between the duration of dominance of the ovulatory follicle and pregnancy rate in beef heifers. Reproduction 102: 123-130

Nakao T, Shirakawa J, Tsurubayashi M, Ohboshi K, Abe T, Sawamukai, Y, Kawata K (1984) A preliminary report on the treatment of ovulation failure in cows with gonadotropin-releasing hormone analog or human chorionic gonadotropin combined with insemination. Anim Reprod Sci 7: 489-495

Nanda AS and Singh J(2008) Factors responsible for increased calving intervals in crossbred cows in India. In: Nanda, A.S. (ed.), Proceedings of XXV World Buiatrics Congress; 3rd to 6th December, Budapest, Hungary. pp. 100- 107

Nath M (2014). Addressing prolonged oestrus in crossbred cows, MVSc. Thesis, Assam Agricultural University, Khanapara, Guwahati, Assam

Nath M, Deka KC, Nath KC, Borah P, Sarmah BK, Bora DP (2019) Incidence and Haemato-biochemical profile of prolonged oestrus crossbred cows. J Entomol Zool Stud 7: 989-991

Nebel RL, Dransfield MG, Jobst SM, Bame JH (2000) Automated electronic systems for the detection of oestrus and timing of AI in cattle. Anim Reprod Sci 60: 713-723

Niyas E, Kurien MO, Jayakumar C, Abhilash RS, Anil KS, Reshma S (2019) Sonographic assessment of follicular and luteal characteristics in repeat breeding cattle with prolonged oestrus. Pharma Innovation 8: 486-491

Omari M, Lange A, Plöntzke J, Röblitz S (2020) Model-based exploration of the impact of glucose metabolism on the estrous cycle dynamics in dairy cows. Biol Direct 15: 1-22

Parvathy S (2015) Effect of prostaglandin administration on progesterone levels during oestrus cycle in crossbred cattle showing prolonged oestrus. MVSc. Thesis, Kerala Agricultural University, Thrissur

Pursley JR, Mee MO, Wiltbank MC (1995) Synchronization of ovulation in dairy cows using PGF2áand GnRH. Theriogenology 44: 915-923

Radhika S (2017) Evaluation of ovulation pattern and its relation to fertility in crossbred cows with prolonged estrus. M.V.Sc Thesis, Srivenkateswara veterinary university Tirupati 
Rajamahendran R, Robinson J, Desbottes S, Walton JS (1989) Temporal relationships among estrus, body temperature, milk yield, progesterone and luteinizing hormone levels, and ovulation in dairy cows. Theriogenology 31: 1173-1181

Roth Z, Meidan R, Braw-Tal R, Wolfenson D (2000) Immediate and delayed effects of heat stress on follicular development and its association with plasma FSH and inhibin concentration in cows. J Reprod Fertil 120: 83-90

Satheshkumar S, Brindha K, RoyA, Devanathan TG, Kathiresan D, Kumanan K (2015). Natural influence of season on follicular, luteal, and endocrinological turnover in Indian crossbred cows. Theriogenology 84: 19-23

Satheshkumar S, Subramanian A, Devanathan TG, Kathiresan D, Veerapandian C, Palanisamy A (2012) Follicular and endocrinological turnover associated with GnRH induced follicular wave synchronization in Indian crossbred cows. Theriogenology 77: 11441150

Saumande J, Humblot P (2005) The variability in the interval between estrus and ovulation in cattle and its determinants. Anim Reprod Sci 85: $171-182$

Senthilkumar A, Balamurugan P, Sribalaji N, Srinivasan G (2017) Hydroxy Progesterone, Human Chronic Gonadotropin and GNRH Analogue on Fertility of Repeat Breeding Dairy Cattle in Theni District of Tamilnadu. Int J Sci, Environ and Technol 6: $734-737$

Shakir, A. 2018. Fertility management in crossbred cattle exhibiting prolonged oestrus using PGF2á analogue and ovsynch protocol. M.V.Sc Thesis, Kerala Veterinary and Animal Sciences University, Pookode

Sharma A, Singh M, Vasishta NK (2006). Effect of gonadotrophin releasing hormone administration on conception rate following artificial insemination in repeat breeder cattle. Indian J Anim Sci 76: 330332
Shaw DW(1999) Use of GnRH to enhance pregnancy rates and shorten the postpartum interestrus interval in dairy cattle. Newsletter of the Society for Theriogenology 9-10

Shelar RR, Deopurkar VL, Bakshi SA, Gulavene SU (2002) Efficacy of preinsemination $\mathrm{GnRH}$ treatment on the conception rate in repeat breeder cows. Blue Cross Book 19: 26-27

Singh B, Saravia F, Båge R, Rodríguez-Martínez H (2005) Pregnancy rates in repeat-breeder heifers following multiple artificial inseminations during spontaneous oestrus. Acta Vet Scand 46: 1-12

Singh J, Dadarwal D, Honparkhe M, Dhaliwal GS, Ghuman SPS (2009) Prolonged estrus in repeat breeding cross-bred cows: incidence, hormonal profile and ovarian dynamics. Project report. ICAR, New Delhi, India

Singh J, Ghuman SPS, Honparkhe M, Dadarwal D, Dhaliwal GS (2012) Risk factors for prolonged estrus in crossbred dairy cattle. Indian $\mathrm{J}$ Anim Sci 82: 20

Singh KJ (2003) Ovulation and fertility in relation to duration of estrus in crossbred cattle. M.V.Sc. Thesis, Punjab Agricultural University, Ludhiana

Stevenson JS, Lamb GC, Kobayashi Y, Hoffman DP (1998) Luteolysis during two stages of the estrous cycle: subsequent endocrine profiles associated with radiotelemetrically detected estrus in heifers. J Dairy Sci 81: 2897-2903

Stevenson JS, Phatak AP, Rettmer IMMO, Stewart RE (1993) Postinsemination administration of receptal: follicular dynamics, 